\title{
SEASONAL VARIATION OF SURFACE ENERGY BALANCE OVER TWO SAHELIAN SURFACES
}

\author{
A. VERHOEF ${ }^{\mathrm{a}, *}$, S.J. ALLEN ${ }^{\mathrm{a}, \mathrm{b}}$ and C.R. LLOYD ${ }^{\mathrm{a}}$ \\ a Institute of Hydrology, Wallingford, Oxfordshire, OX10 8BB, UK \\ ${ }^{\mathrm{b}} \mathrm{CECS}$, University of Edinburgh, Edinburgh EH9 3JK, UK
}

\author{
Received 17 March 1998 \\ Revised 21 January 1999 \\ Accepted 6 February 1999
}

\begin{abstract}
The seasonal variation of the surface energy balance (SEB) (net radiation, soil heat flux, and sensible and latent heat fluxes) for a savanna and an open natural forest (tiger-bush) located in the Sahel is presented. Daily averages of these four fluxes were obtained using standard micrometeorological instruments/methods (radiometry, soil heat flux plates and the eddy correlation technique). Because sensible and latent heat flux data were not available during the dry season (and occasionally missing during the wet season), estimates from a simple linear equation, which relates sensible heat flux to the difference between surface and air temperature, were used instead. This produced a practically continuous time series of the surface energy balance for a period of over 1 year. Net radiation over both surfaces appeared to be very similar, varying roughly between $75 \mathrm{~W} \mathrm{~m}^{-2}$ (dry winter months) and $175 \mathrm{~W} \mathrm{~m}^{-2}$ (wet summer months) on a daily basis. During the winter months, soil heat flux had maximum values of about $-8 \mathrm{~W}$ $\mathrm{m}^{-2}$, while maximum values during the summer were approximately $+8 \mathrm{~W} \mathrm{~m}^{-2}$. Sensible heat flux varied between approximately $20 \mathrm{~W} \mathrm{~m}^{-2}$ (wet season) and $100 \mathrm{~W} \mathrm{~m}^{-2}$ (end of dry season) with generally slightly higher values for the savanna than for the tiger-bush, especially during the dry autumn and winter months. During the wet season, evaporation reached values of $100-150 \mathrm{~W} \mathrm{~m}^{-2}$. Both surfaces were predicted to exhibit some evaporation during the dry season; approximately $5-10 \mathrm{~W} \mathrm{~m}^{-2}$ for the savanna and approximately $20 \mathrm{~W} \mathrm{~m}^{-2}$ for the tiger-bush. The course of these fluxes is supported by secondary observations such as rooting depth and greenness of the vegetation, indicating that this method may be a useful tool if gaps in long-term time series exist. The information presented will be useful as verification data for climate modelling and can be used as ground truth data for remote sensing. Copyright (C) 1999 Royal Meteorological Society.
\end{abstract}

KEY WORDS: surface energy balance; seasonal variation; Sahel; savanna; tiger-bush

\section{INTRODUCTION}

A continuous exchange of energy takes place between the Earth's surface and the atmosphere. These land surface-atmosphere interactions can be described by the surface energy balance (SEB):

$$
R_{\mathrm{n}}=H+L E+G
$$

(see Garratt (1992), for example). Assuming that horizontal flux divergence and heat storage are insignificant, Equation (1) states that the net radiation $\left(R_{\mathrm{n}}\right)$, is dissipated as sensible heat $(H)$, evaporation ( $L E$, where $L$ is the latent heat of vaporisation and $E$ is the evaporation rate) and soil heat $(G)$ fluxes.

For many decades, meteorologists have tried to quantify the SEB by making direct ground measurements. These efforts were often confined to the temperate parts of the world, and to economically important vegetation such as agricultural crops, pasture or forest (for example, Stewart and Thom (1973)). Recently, experimental interest has shifted more to the semi-arid and arid areas which cover nearly $40 \%$ of the world (for example, FIFE (Sellers et al., 1988), Sahelian Energy Balance Experiment

\footnotetext{
* Correspondence to: Institute of Hydrology, Wallingford, Oxfordshire, OX10 8BB, UK. Tel.: + 4401491692335 , fax: + 4401491 692424; e-mail: A.Verhoef@mail.nwl.ac.uk
}

CCC 0899-8418/99/111267-11\$17.50

Copyright (C) 1999 Royal Meteorological Society 
(SEBEX) (Wallace et al., 1992), EFEDA (Bolle et al., 1993) and HAPEX-Sahel (Goutorbe et al., 1994)), following pioneering work carried out in semi-arid Australia (Garratt, 1978) and the development of portable measurement systems which facilitated monitoring under more extreme climatic conditions. Comparatively little is known about the SEB in these areas, and more insight is needed into their considerable influence on global circulation, to predict the effects of climate and land use change (ICIIHI, 1986).

This paper is concerned with estimating the SEB of natural vegetation in the Sahel. During the 20th century the Sahel has experienced at least seven severe droughts, with serious impacts on agricultural production (Wessels, 1993). The continuing pressure on land has resulted in the utilisation of marginal areas, the shortening of the fallow period leading to a decrease in soil fertility and environmental degradation, allowing wind and water erosion to take their toll and the desertification process to begin. To understand desertification, continuous monitoring of the Sahelian surface must be carried out. There have been meteorological campaigns to observe the Sahel during the past (Druilhet and Tinga, 1982; Pagès et al., 1988; Wallace et al., 1992; Goutorbe et al., 1994). In combination with these, remote sensing (Kerr et al., 1987; Seguin et al., 1989) and modelling (Blyth and Harding, 1995) appeared to be useful. However, in many cases these efforts involved relatively short, intensive measurement campaigns (1-3 months, mainly during the wet season).

This paper gives an example of the SEB over a longer period using micrometeorological data obtained over a fallow savanna and a natural forest, generally referred to as tiger-bush because of its similarity to a tiger skin when viewed from the air, during SEBEX (Wallace et al., 1992). Furthermore, it describes how missing daily values of $H$ (and $L E$, from $R_{\mathrm{n}}-H$ ) were estimated, thereby reconstructing the seasonal course of these fluxes, using a relatively simple equation, often used for remote sensing purposes, employing values of daily surface temperature, maximum air temperature.

\section{MATERIALS AND METHODS}

\subsection{Experimental sites}

Micrometeorological measurements over both fallow savanna and tiger-bush were made by the Institute of Hydrology (Wallingford, UK) at the International Center for Research in the Semi-Arid Tropics (ICRISAT) Sahelian Center (ISC, Latitude $13^{\circ} 15^{\prime} \mathrm{N}$, Longitude $2^{\circ} 17^{\prime} \mathrm{E}$ ) through the years $1988-1990$ during SEBEX. The fallow savanna site (size: approximately $800 \times 2000 \mathrm{~m}$ ), which had been uncultivated for over 7 years, was within the boundary fence of the ISC. Eighty-one percent of the ground area was covered with a mixture of annual leguminous and grass species whereas the remainder was covered with Guiera senegalensis shrubs with an average height of $2.3 \mathrm{~m}$, and occasional trees. The soil on the savanna site is very sandy and about $0.5 \mathrm{~m}$ deep, overlying laterite rock. The tiger-bush site is located about $6 \mathrm{~km}$ southwest of ISC within an area of open natural forest covering an irregular-shaped plateau $3 \mathrm{~km}$ wide. The vegetation, covering about $33 \%$ of the ground surface, consists of dense bands about $10-30 \mathrm{~m}$ wide by $100-300 \mathrm{~m}$ long separated by completely bare crusted soil. The vegetation is dominated by two species of 2-4 $\mathrm{m}$ tall shrubs (Combretum micranthum and Guiera senegalensis) and a single tree species (Combretum nigricans), typically between 4 and $8 \mathrm{~m}$ tall. The soil on the site is a laterite with a fine to coarse sandy matrix. The soil layer is very thin, only about $0.2-0.5 \mathrm{~m}$ deep and overlies laterite rock. For more details see Gash et al. (1991), Wallace et al. (1992) and Culf et al. (1993).

This paper uses micrometeorological data obtained during SEBEX between 15 July 1989 and 30 September 1990. Observations during 1988 were incomplete and are therefore not used. Annual rainfall at the ISC for the years 1989 and 1990 was 623 and $400 \mathrm{~mm}$, respectively. Considering a 10-year (1983-1993) average of $536 \mathrm{~mm}$ as measured at ISC, 1989 can be considered as relatively wet, while 1990 was dry. Daily totals of rainfall as measured at the two sites are given in Figure 1. For this area, the bulk of the rainfall usually occurs between July and October, as illustrated in Figure 1, which shows no rainfall between 10 October 1989 and 7 May 1990. 


\subsection{Instrumentation}

The net all-wave radiation flux density, $R_{\mathrm{n}}$, consists of the following combination of radiation terms:

$$
R_{\mathrm{n}}=R_{\mathrm{s}, \downarrow}-R_{\mathrm{s}, \uparrow}+R_{1, \downarrow}-R_{1, \uparrow}
$$

where $R_{\mathrm{s}}$ is the total shortwave solar radiation flux density and $R_{1}$ the longwave radiation flux density, with upward and downward arrows representing outgoing and incoming fluxes, respectively. The ratio of reflected and incoming solar radiation $\left(R_{\mathrm{s}, \uparrow} / R_{\mathrm{s}, \downarrow}\right)$, is called the albedo.

The individual terms of Equation (2) were measured at both experimental sites. Shortwave radiation sensors (Kipp and Zonen, Delft, The Netherlands) were deployed for the measurement of $R_{\mathrm{s}, \downarrow}$ and $R_{\mathrm{s}, \uparrow}$. The heights of the sensors measuring $R_{\mathrm{s}, \downarrow}$ were 9.2 and $11.0 \mathrm{~m}$ for fallow savanna and tiger-bush, respectively. At each site, $R_{\mathrm{s}, \uparrow}$ over the two main surface components was measured independently, providing measurements over four surfaces with plant cover ranging from zero (bare soil at tiger-bush site) to dense (tiger-bush vegetation strips). The reflected radiation sensors were mounted above the surfaces on horizontal booms, to minimise the possibility of shadowing by support structures. At the fallow savanna site the instruments were mounted at a height of $6.5 \mathrm{~m}$ for the undergrowth and $3.4 \mathrm{~m}$ for the bushes. At the tiger-bush site sensor heights were $1.4 \mathrm{~m}$ (soil) and $8.2 \mathrm{~m}$ (vegetation strips). More details about the measurement and values of albedo are given by Allen et al. (1994). Longwave incoming radiation, $R_{1, \downarrow}$, was measured with a pyrgeometer (Eppley Laboratory, Rhode Island, USA) at the tiger-bush site and its values were corrected for influence of $R_{\mathrm{s}, \downarrow}$ (Culf and Gash, 1993). These $R_{1, \downarrow}$ values were also used for the savanna site as spatial variation in $R_{1, \downarrow}$ is small. Outgoing longwave radiation was estimated from $R_{1, \uparrow}=\varepsilon \sigma T_{\mathrm{s}}^{4}$, with $\varepsilon$ the surface emissivity, $\sigma$ the Stefan-Boltzmann constant $\left(\mathrm{W} \mathrm{m}^{-2} \mathrm{~K}^{-1}\right)$ and $T_{\mathrm{s}}$ the surface temperature $(\mathrm{K})$. Infrared thermometers were used to measure $T_{\mathrm{s}}$ (IRT, Model 4000 series, Everest Interscience, Fullerton, California, USA). They operated over $8-14 \mu \mathrm{m}$, with a $15^{\circ}$ field of view. At the fallow savanna, two IRTs viewed the undergrowth component of the vegetation (sensor height $6.0 \mathrm{~m}$ ) while the other four were positioned over individual bushes (sensor height $3.5 \mathrm{~m}$ ). The
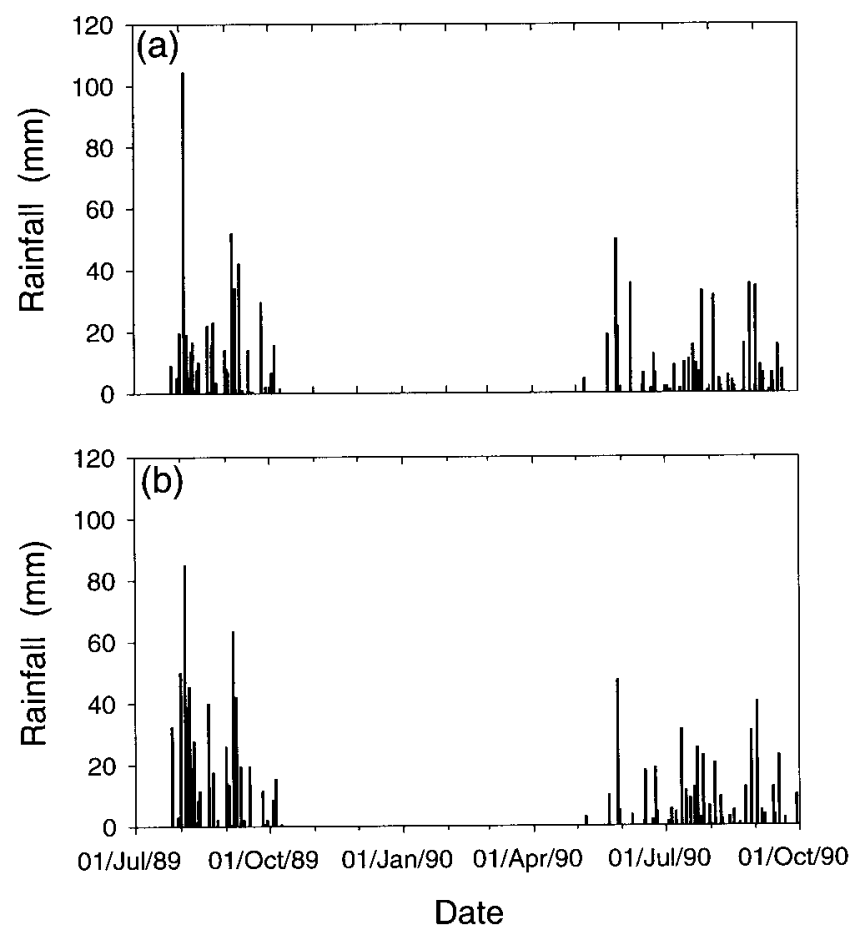

Figure 1. Daily total rainfall during SEBEX 1989-1990 for (a) the savanna and (b) the tiger-bush site 
individual IRT measurements were weighted by the average proportion of each of the vegetation components to form an areal average value. For the tiger-bush, site three IRTs were mounted over the vegetation (sensor heights $9.0-10.0 \mathrm{~m}$ ) and three over the bare soil strips (sensor height $3.5 \mathrm{~m}$ ). Instrument outputs were measured every five seconds with solid-state dataloggers (CR10, Campbell Scientific, Shepshed, UK) and stored as hourly means (Wallace et al., 1992). From the separate measurements of the four components of net radiation described, a composite value of $R_{\mathrm{n}}$ was calculated for each surface (savanna bushes, savanna herb layer, tiger-bush vegetation strips and tiger-bush bare soil). Direct measurements of $R_{\mathrm{n}}$ for these four component surfaces were obtained, initially using Q*5 double-domed radiometers and, from April 1990, single-domed Q*6 radiometers (REBS, Seattle, USA), mounted at the same height as the sensors measuring reflected solar radiation. The net radiation fluxes over the component surfaces, both from direct measurement and calculated from Equation (2), were upscaled using:

$$
R_{\mathrm{n}}=\alpha R_{\mathrm{n}, \mathrm{u}}+(1-\alpha) R_{\mathrm{n}, \mathrm{b}}
$$

to obtain $R_{\mathrm{n}}$ values valid for the total savanna and tiger-bush surfaces. In this equation, $\alpha$ is the surface coverage of the understorey ( 0.81 and 0.67 for the savanna and tiger-bush, respectively), $R_{\mathrm{n}, \mathrm{u}}$ is the net radiation over the understorey (herb layer or bare soil) and $R_{\mathrm{n}, \mathrm{b}}$ is the net radiation over the bushes.

Measurements of $G$ in the fallow savanna were made using three sets of three small heat flux plates (Model 610, Thornthwaite, USA), with two sets beneath two bushes and one set beneath an area of the herb layer. Similar $G$-flux plates were placed at the tiger-bush site with five plates beneath the bushes and four plates beneath the bare soil. All sensors were located about $5 \mathrm{~mm}$ below the surface.

Measurements of $L E$ and $H$ were made using the eddy correlation technique by the IH Hydra (Shuttleworth et al., 1988). Over the savanna site, the Hydra was installed at a height of $12.3 \mathrm{~m}$. At the tiger-bush site the Hydra was mounted at a height of 15.9 m. From January 1989 until May 1990 no $H$ and $L E$-flux data were recorded.

Daily $(24 \mathrm{~h})$ averages of flux measurements in $\mathrm{W} \mathrm{m}^{-2}$ have been calculated from hourly data.

\subsection{Empirical equation for $H$}

Hourly measurements of air and surface temperature allowed daily average $H$ to be estimated following a relationship similar to that originally proposed by Jackson et al. (1977) and which has been used by Søgaard (1988), Seguin et al. (1989), Lagouarde and McAneney (1992), and Sandholt and Steen Andersen (1993), among others:

$$
H_{\mathrm{est}}=a\left(T_{\mathrm{s}, 1400}-T_{\mathrm{a}, \max }\right)+b
$$

with $T_{\mathrm{s}, 1400}$ being the surface temperature at 14:00 $\mathrm{h}$ LST and $T_{\mathrm{a}, \max }$ the maximum air temperature during a certain day. In Equation (4), $H_{\text {est }}$ is in $\mathrm{mm}_{\text {day }}{ }^{-1}$, which can be converted to $\mathrm{W} \mathrm{m}^{-2}$ through division by 0.0353 . The constants $a$ and $b$ were estimated from the experimental data. An estimate of $L E, L E_{\text {est }}$, was found from $R_{\mathrm{n}}-H_{\text {est }}$ (assuming $G$ is approximately 0 over a $24 \mathrm{~h}$ period). The occasional occurrences of negative values of $L E_{\text {est }}$ were rejected.

\section{RESULTS AND DISCUSSION}

As explained above, values of $R_{\mathrm{n}}$ were obtained both in a direct and an indirect way (using Equation (2)). In theory, direct measurements should be in close agreement with the composite $R_{\mathrm{n}}$ data, both on a diurnal and a seasonal scale. Spatial variability, instrumental set-up, and measurement errors can cause a difference between directly measured and composite $R_{\mathrm{n}}$. Keeping this in mind, the best and most plausible values of $R_{\mathrm{n}}$ have to be selected and used for further calculation.

Verhoef (1995) compared both estimates of $R_{\mathrm{n}}$ for the two SEBEX surfaces and showed that the savanna $R_{\mathrm{n}}$ data exhibited a good correspondence $\left(r^{2}=0.96\right)$, with an average overestimation of directly 
measured compared to composite $R_{\mathrm{n}}$ of only $6 \%$. For the tiger-bush however, the directly measured $R_{\mathrm{n}}$ was $20 \%$ lower than the composite $R_{\mathrm{n}}$, although the trend between both $R_{\mathrm{n}}$ estimates was similar $\left(r^{2}=0.88\right)$. This may be partly attributed to the bush net radiometer (installed at $\left.8.2 \mathrm{~m}\right)$ including some bare soil in its field of view. This phenomenon was also found for the HAPEX-Sahel tiger-bush site (Verhoef, 1995), and illustrates how large errors can occur when attempting to measure fluxes over specific surface components in heterogeneous terrain using hemispheric integrating sensors. However, the directly measured $R_{\mathrm{n}}$ values for the tiger-bush soil were also quite low compared to its composite estimate. This might have been caused by spatial variability, which will be much greater for the bare soil patches than for the vegetation strips. Furthermore, the fact that double-domed net radiometers were replaced with single-domed radiometers after April 1990, and knowing that a significant offset between the two types of instruments exists (Oliver and Wright, 1990), led to the decision to use the composite measurements of $R_{\mathrm{n}}$, rather than the direct measurements.

Seasonal variation of composite $R_{\mathrm{n}}$ over the savanna and tiger-bush during the wet and dry seasons of SEBEX 1989-1990 is shown in Figure 2(a). The gap during the wet season of 1990 is caused by a lack of surface temperature data, which are necessary to calculate $R_{1, \uparrow}$ (Figure 2(e)). Figure 2(a) shows that the savanna and the tiger-bush surface have a very similar seasonal course in $R_{\mathrm{n}}$.

Daily averages of $R_{\mathrm{n}}$ vary between roughly 50 and $200 \mathrm{~W} \mathrm{~m}^{-2}$. The lowest values are found during the 'winter months' occurring during the dry season, whereas the highest values were observed during the peak of the wet season. During the dry winter months, low $R_{\mathrm{n}}$ was the result of a combination of relatively low $R_{\mathrm{s}, \downarrow}\left(150-250 \mathrm{~W} \mathrm{~m}{ }^{-2}\right.$ compared to spring and summer values of up to $300 \mathrm{~W} \mathrm{~m}^{-2}$ ), as illustrated in Figure 2(b), high albedo values (approximately 0.24 and 0.27, for the savanna and tiger-bush, respectively compared to values of 0.17 and 0.22 at the peak of vegetation growth during the rainy season, see Figure 2(c)) caused by drying out of vegetation and soil, and low values of incoming longwave radiation (approximately $350 \mathrm{~W} \mathrm{~m}^{-2}$ in contrast with summer values of up to $450 \mathrm{~W} \mathrm{~m}^{-2}$, as shown in Figure 2(d), because of low atmospheric emissivity and relatively low air temperatures). Low values of $R_{1, \uparrow}$ during the winter months (Figure 2(e)), mainly a result of $R_{1, \uparrow}$ relatively low air temperatures and hence lower surface temperatures, prevent $R_{\mathrm{n}}$ from becoming even lower.

With increasing solar elevation and air temperatures during spring, both $R_{\mathrm{s}, \downarrow}$ and $R_{1, \downarrow}$ and hence $R_{\mathrm{n}}$, increase considerably, even though at the same time $R_{1, \uparrow}$ increases. During these months, albedo stays virtually constant (Allen et al., 1994). After the onset of the rains, albedo values, especially those for the savanna, decrease rapidly, while $R_{\mathrm{s}, \downarrow}$ and $R_{1, \downarrow}$ level off.

The SEBEX groundbeat fluxes were measured with $G$-flux plates installed at a rather shallow depth (5 $\mathrm{mm})$. However, to avoid the plate influencing the surface conditions through convective and radiation errors (Oke, 1987; Mayocchi and Bristow, 1995) such plates are usually installed at a greater depth $(0.05$ $\mathrm{m}$, for example) with at least one temperature sensor placed between the plate and the surface in order to calculate heat storage in that layer. The shallow installation during SEBEX caused the vast majority of the daily averages to be positive, suggesting an apparent ongoing warming of the ground. Besides, when the evaporation front is below the plate, part of the measured $G$ will originate from the evaporation process (Mayocchi and Bristow, 1995). This is an extra reason for measured $G$ to be too positive during the wet season. Therefore, the annual course of the daily averaged $G$ values for the four subsurfaces presented in Figure 3 has been corrected. For this graph, 5-day averages of $G$ have been calculated to smooth the rather irregular character of this flux. Results from 1989 and 1990 have been combined and Figure 3, therefore, shows $G$ against the day of year. To obtain Figure 3, the original data points have been shifted downwards (by $-10 \mathrm{~W} \mathrm{~m}^{-2}$ for Figure 3(a), and by $-5 \mathrm{~W} \mathrm{~m}^{-2}$ for Figure 3(b)), for reasons described above, to ensure an annual mean $G$ of approximately $0 \mathrm{~W} \mathrm{~m}^{-2}$. This shift resulted in a range of (wet season) values that was very similar to the daily averages calculated during the HAPEX-Sahel measurement campaign at similar sites in Niger (Verhoef, 1995).

Figure 3(a) shows the daily average $G$-flux for the savanna understorey and the tiger-bush soil. Highest positive values are observed during the wet season, both for the savanna and tiger-bush. Figure $3(\mathrm{~b})$ shows $G$ as measured beneath the bushes. As a result of shading by the bush canopies, values are much smaller than for the fallow savanna understorey or tiger-bush bare soil and seasonal variation is hardly 

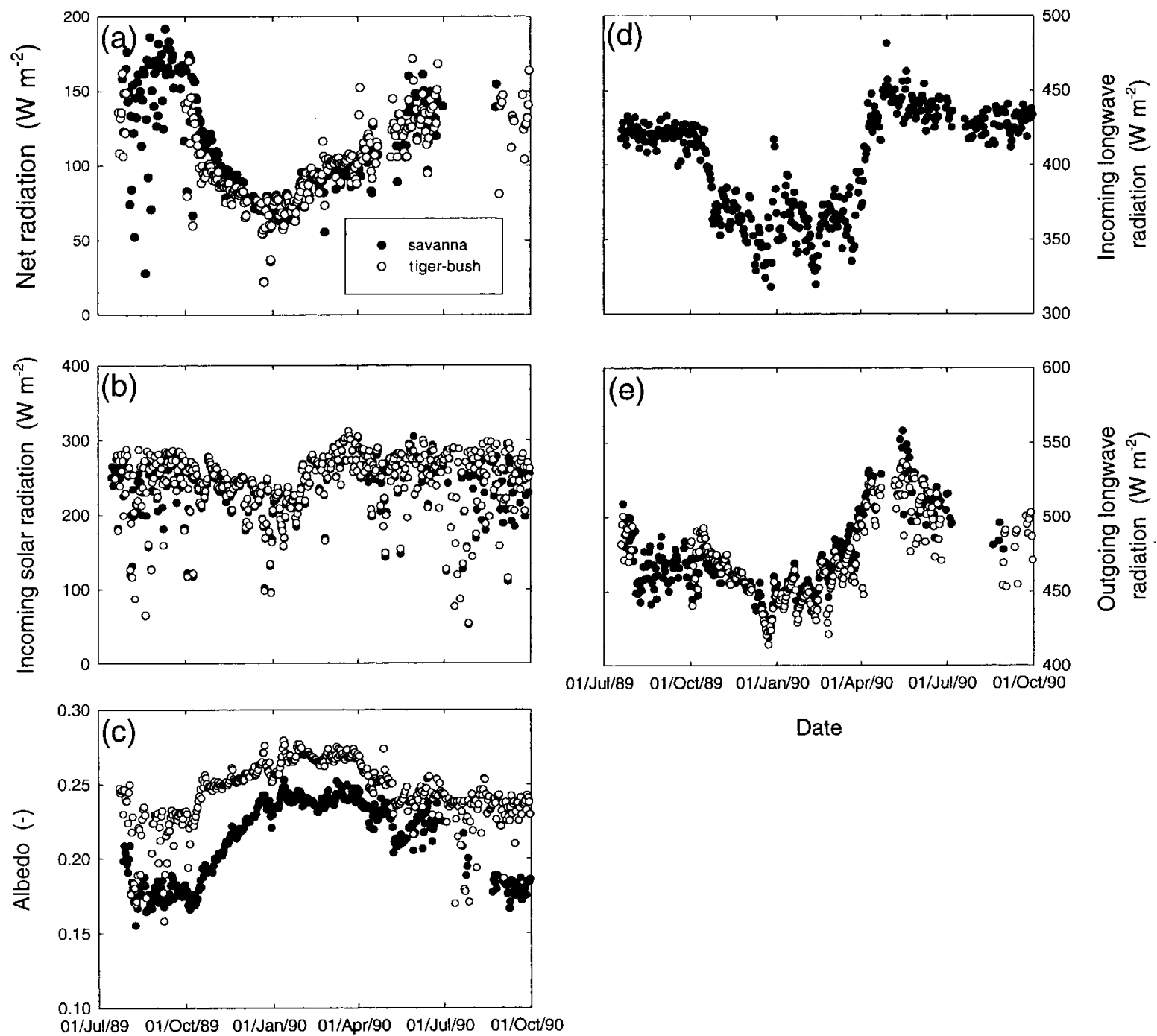

Date

Date

Figure 2. Seasonal variation in daily mean $R_{\mathrm{n}}$ (a), daily mean $R_{\mathrm{s}, \downarrow}$ (b), area-averaged daily mean albedo $\left(R_{\mathrm{s}, \uparrow} / R_{\mathrm{s}, \downarrow}\right)$ (c), daily mean $R_{1, \downarrow}(\mathrm{d})$ and $R_{1, \uparrow}$ (e) for the savanna and tiger-bush sites during the wet and dry seasons of SEBEX 1989-1990

present. Values for the Guiera bushes and the tiger-bush vegetation strips are similar. To calculate the average $G$ value for the total surface, the coverages of the component surfaces have to be taken into account (as for $R_{\mathrm{n}}$, see Equation (3)), leading to maximum absolute $G$ values of approximately $8 \mathrm{~W} \mathrm{~m}^{-2}$. These values of $G$ are small compared to values for $R_{\mathrm{n}}$, and it is therefore reasonable to assume that $G$ (on a daily basis) is approximately 0 .

Directly measured $H$ - and $L E$-fluxes, derived from composite $R_{\mathrm{n}}-H$, are given in Figure 4 for both surfaces. Because of suspected problems with measurement of $L E$, especially for tiger-bush, resulting in relatively poor energy closure (Verhoef, 1995), values of $L E$ presented in Figures 4 and 5 are the residual of the energy balance and not the direct measurements obtained from the eddy correlation technique. Figure 4 shows that $H$ varies between roughly $10 \mathrm{~W} \mathrm{~m}^{-2}$ (end of wet season) and $100 \mathrm{~W} \mathrm{~m}^{-2}$ (end of dry season). A large scatter is observed, but a clear downward trend after the beginning of the rains occurs, which is clearly illustrated by the datapoints of 1990 . During the rainy season, $H$ over the 

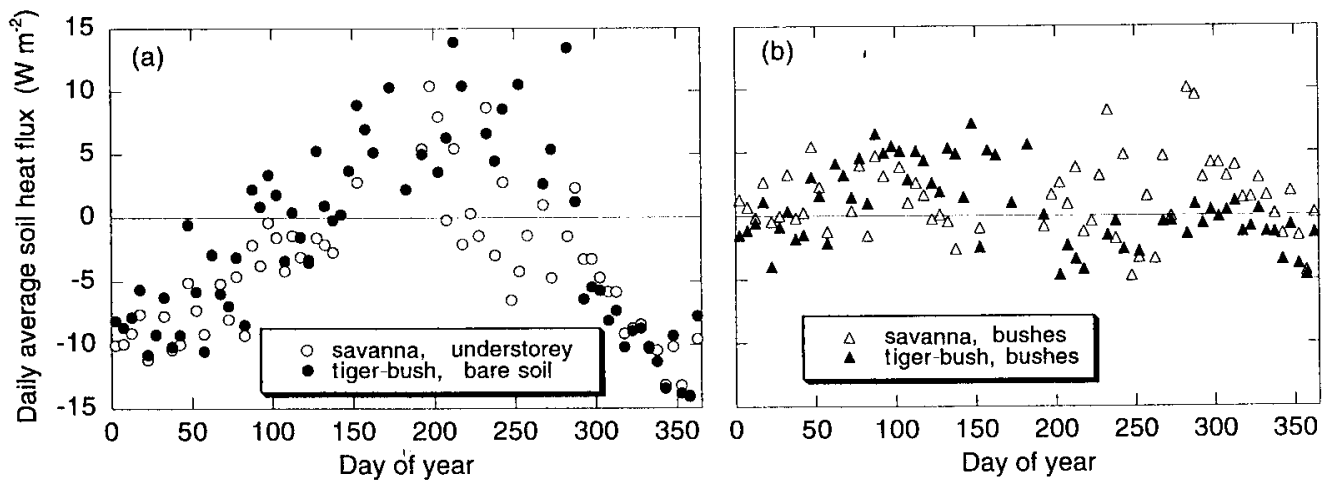

Figure 3. (a) Annual course of daily averages of $G$ for the savanna understorey or tiger-bush soil and (b) $G$ below the savanna bushes or tiger-bush vegetation strips. Daily averages are over 5-day periods and plotted at the middle of this interval. No distinction was made between the years 1989 and 1990

tiger-bush appears to be similar or slightly higher than $H$ observed over the savanna. During the dry-out period (October-December 1989) however, $H$ over the tiger-bush is considerably lower than over the savanna, for reasons explained below.

The $L E$ shows an opposite course; for the savanna, $L E$ ranges from approximately $10 \mathrm{~W} \mathrm{~m}^{-2}$ before the rains to $150 \mathrm{~W} \mathrm{~m}^{-2}$ at the peak of the rainy season. Values for tiger-bush during the wet seasons are generally lower, but well after the rainy season in 1989 (i.e. November-December), $L E$ of the tiger-bush is considerably higher than the savanna values. This is probably caused by the fact that the tiger-bush vegetation includes deeper rooting trees (such as Combretum nigricans) which allows the usage of deeper soil water (Wallace et al., 1992; Culf et al., 1993). The higher density of the vegetation strips also reduces evaporation from the underlying soil, thus enabling the vegetation to stay green longer. The majority of the undergrowth species in the savanna are shallowly rooted annuals and therefore die off quickly after the end of rains. Tiger-bush $L E$ increases (early May 1990) before the real onset of rains (3 mm of rain fell on 7 May, after which no rainfall occurred until 23 May) which suggests that green leaf area already starts to develop in the dry season. This is a regularly observed phenomenon in these semi-arid regions (Von Maydell, 1990; Wallace et al., 1992). It is supposed that some Sahelian shrub species (among them Guiera senegalensis) have underground storage organs from which they extract water before and during the beginning of the wet season.

Figure 5 shows the evolution of Bowen ratio, $H / L E$, during SEBEX. A 100-fold difference between wet and dry season was observed, with values ranging from approximately 0.1 to 10 . Although tiger-bush

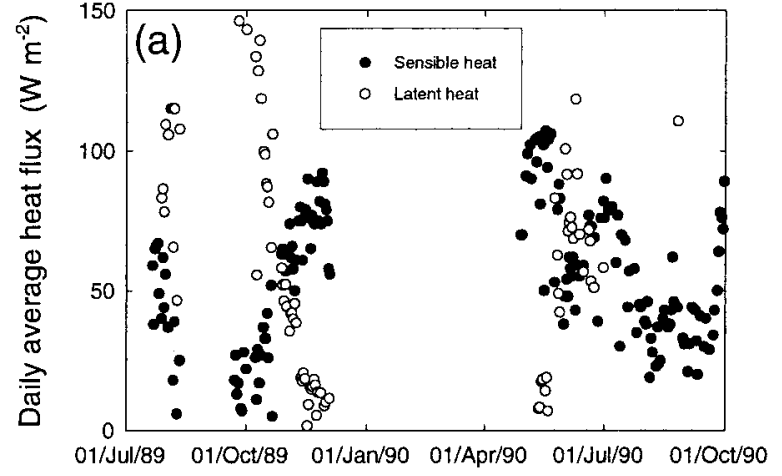

Date

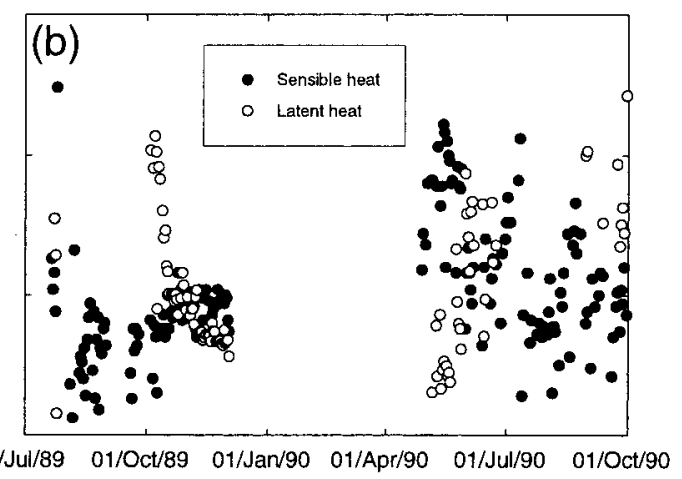

Date

Figure 4. (a) $H$ - and $L E$-fluxes for the SEBEX savanna (a) and tiger-bush (b) surfaces. $L E$ is the residual term of the energy balance $\left(R_{\mathrm{n}}-H\right)$ 


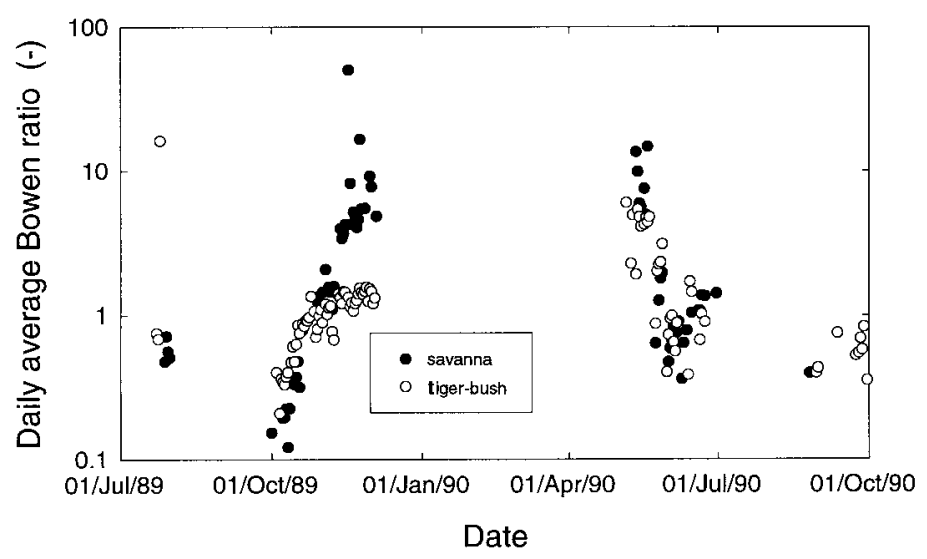

Figure 5. Bowen ratio evolution for savanna and tiger-bush during the years 1989 and 1990 of the SEBEX campaign

values are similar to, or higher than values observed for the savanna during the rainy period (as also observed during the 1992 HAPEX-Sahel campaign), values stayed practically constant during November and December 1989. Just before the onset of rains, the Bowen ratios for both vegetation types were very much alike.

As can be seen in Figures 4 and 5, from January 1989 until May 1990 no atmospheric flux data were recorded. In order to reconstruct a continuous annual course, Equation (4) has been used. Plotting the $H$ values measured with the eddy correlation technique against $\left(T_{\mathrm{s}, 1400}-T_{\mathrm{a}, \max }\right)$ led to values for the constants $a$ and $b$ as given in Table I. Values of $T_{\mathrm{s}, 1400}$ representing the vegetation strips only have been used for the tiger-bush. When average $T_{\mathrm{s}, 1400}$ values representing the total surface (i.e. $T_{\mathrm{s}, 1400}=0.33 T_{\mathrm{s}, 1400}$ (vegetation) $+0.67 T_{\mathrm{s}, 1400}$ (bare soil)) were used, correlation between $\left(T_{\mathrm{s}, 1400}-T_{\mathrm{a}, \max }\right)$ and measured $H$ was very low. This can be explained by the fact that a large amount of the $H$ produced by the bare soil patches is absorbed by the vegetation strips (Blyth and Harding, 1995) and converted to $L E$, and hence does not contribute directly to the measured vertical flux of $H$. This lateral exchange of energy will be much less for the savanna, where differences in surface temperature between the bushes and the understorey are relatively small. Furthermore, vertical exchange of (sensible) heat of the savanna understorey will be relatively efficient, compared to the tiger-bush bare soil, because of its greater roughness length. For the savanna, the average surface temperature, $T_{\mathrm{s}, 1400}=0.19 T_{\mathrm{s}, 1400}$ (bushes) $+0.81 T_{\mathrm{s}, 1400}$ (understorey), was therefore used.

Table I gives the $a$ values, which are very similar to values found by Lagouarde and McAneney (1992) and Søgaard (personal communication, 1994) for comparable surfaces. Correlation between measured and predicted $H$ and $L E$ was satisfactory. The coefficient $a$ has been reported to change with momentum roughness length. Sandholt and Steen Andersen (1993), for example, allowed their $a$ value to vary between 0.25 and 0.50 , changing from the dry to the wet season. In the present case, $a$ was kept constant. Although roughness length will have diminished slightly during the dry season as a result of partial leaf shedding, the main bluff-bodied shrub/tree structure remained, keeping roughness length at a relatively high value.

Table I. Values of constants $a$ and $b$ in Equation (4) for savanna and tiger-bush; values of $r^{2}$ for $H$ - and $L E$-flux predictions are also given

\begin{tabular}{lllll}
\hline & $a$ & $b$ & $\begin{array}{l}r^{2} \\
\left(H \text { versus } H_{\text {est }}\right)\end{array}$ & $\begin{array}{l}r^{2} \\
\left(L E \text { versus } L E_{\text {est }}\right)\end{array}$ \\
\hline Savanna & 0.18 & -0.16 & 0.69 & 0.91 \\
Tiger-bush & 0.20 & 1.48 & 0.79 & 0.89 \\
\hline
\end{tabular}



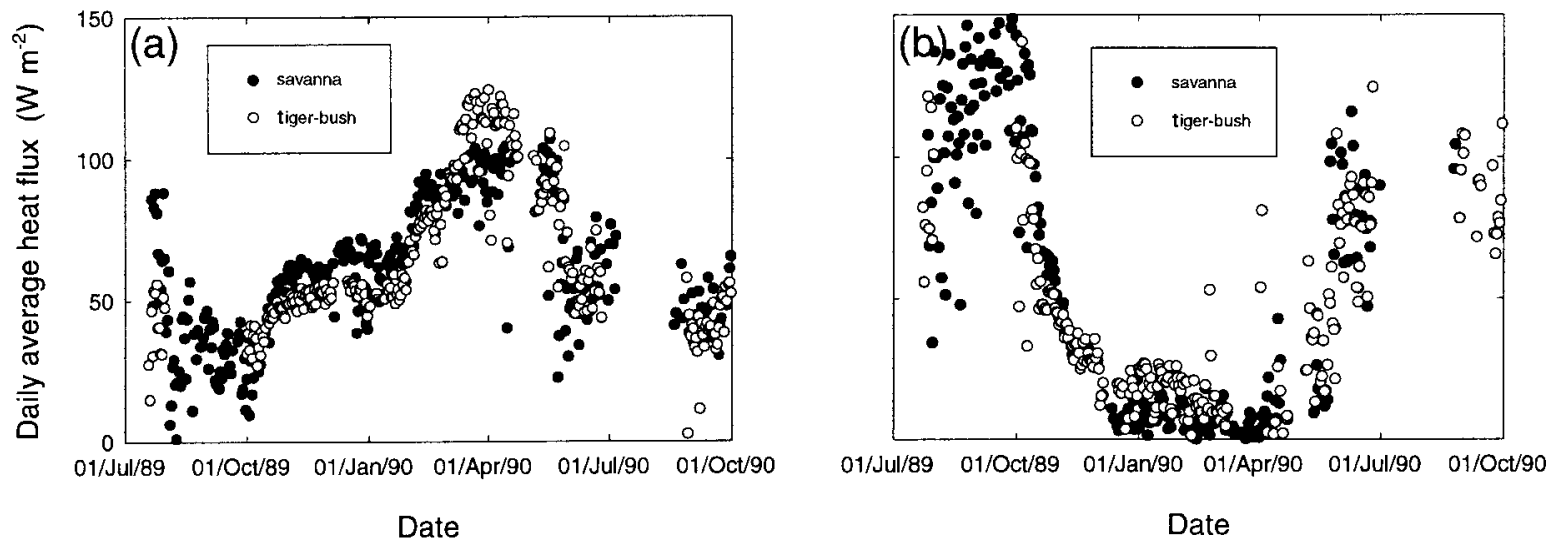

Figure 6. Annual courses of $H$ (a) and $L E$ (b) heat for the SEBEX savanna and tiger-bush surfaces. $H$-fluxes are obtained with $H=a\left(T_{\mathrm{s}, 1400}-T_{\mathrm{a}, \max }\right)+b$ where $a$ and $b$ are given in Table I. $L E$ was found from $\left(R_{\mathrm{n}}-H\right)$. Negative values of $L E$ were rejected

Figure 6(a) shows the annual course of $H_{\text {est }}$, as obtained from Equation (4), with $a$ and $b$ values as shown in Table I, for both savanna and tiger-bush. Highest values were calculated at the end of the dry season (April-May 1990) and lowest values at the end of the wet season (when green leaf area index is at a maximum), which is similar to the measured course of $H$.

Figure 6(b) shows the annual course of $L E_{\text {est }}\left(R_{\mathrm{n}}-H_{\text {est }}\right)$ for both surfaces. During a short period after the last rainfall in $1989, L E_{\text {est }}$ for the tiger-bush is lower than $L E_{\text {est }}$ for the savanna (the latter having a green understorey). However, $L E_{\text {est }}$ of the savanna very soon falls below the values calculated for tiger-bush. During the dry season, the $L E$-flux seems to continue at a low rate for both surfaces, but especially for the tiger-bush location, which, as explained above, may be caused by the deeper rooting species (Moncrieff et al., 1997; Wallace and Holwill, 1997). The ongoing transpiration process probably uses part of the $H$ originating from the bare soil patches (Blyth and Harding, 1995), which explains the comparatively low $H_{\text {est }}$ depicted for tiger-bush in Figure 6(a).

\section{CONCLUSIONS}

The annual course of the surface energy balance of two Sahelian surfaces (savanna and tiger-bush) has been presented. The net radiation of both surfaces appears to be very similar, with $R_{\mathrm{n}}$ varying between roughly $75 \mathrm{~W} \mathrm{~m}^{-2}$ (dry winter months) and $175 \mathrm{~W} \mathrm{~m}^{-2}$ (wet summer months) on a daily basis. During the winter months $G$ had maximum values of about $-8 \mathrm{~W} \mathrm{~m}^{-2}$, hence the soil was cooling down, while maximum values during the summer, were approximately $+8 \mathrm{~W} \mathrm{~m}^{-2}$, meaning that the soil was storing heat. This implies that $G$ was usually around $5-10 \%$ of $R_{\mathrm{n}}$, so using $G$ as 0 is a reasonable approximation.

As a result of a lack of atmospheric flux measurements, especially during the dry season, a simple method was used where daily values of $H$ can be found from maximum air temperature and surface temperature, $T_{\mathrm{s}}$, at 14:00 $\mathrm{h} \mathrm{LST}$. It appeared to give good results for this Sahelian savanna and tiger-bush. This method was used to estimate the seasonal course of $H$ and $L E$ (found from $R_{\mathrm{n}}-H$ ).

This equation for estimation of $H$ has been used before, but mainly for remote sensing purposes (Seguin et al., 1989; Sandholt and Steen Andersen, 1993), where instantaneous satellite data have been used to derive estimates of $T_{\mathrm{s}}$ and $R_{\mathrm{n}}$. However, this type of application leads to a relatively high uncertainty in flux estimates as a result of the necessary corrections involved in remote sensing and because instantaneous estimates of $R_{\mathrm{n}}$ have to be converted empirically to daily averages. In this paper, $T_{\mathrm{s}}$ and $R_{\mathrm{n}}$ were obtained from ground-based hourly values, which improves the reliability of the $H$-flux estimates considerably. 
The annual course constructed in this way, revealed that $H$ varied between approximately 20 and 100 $\mathrm{W} \mathrm{m} \mathrm{m}^{-2}$, where the latter values were calculated just before the start of the rainy season. Generally, the savanna was found to have higher $H$ values than the tiger-bush.

During the wet season evaporation reached values of $100-150 \mathrm{~W} \mathrm{~m}^{-2}$. Both surfaces appeared to exhibit some evaporation during the dry season: approximately $5-10 \mathrm{~W} \mathrm{~m}^{-2}$ for the savanna and approximately $20 \mathrm{~W} \mathrm{~m}^{-2}$ for the tiger-bush. The course of these fluxes is supported by secondary observations such as rooting depth and greenness of the vegetation, indicating that this method may be a useful tool, if gaps in long-term time series exist.

\section{ACKNOWLEDGEMENTS}

The authors want to thank all the people at the Institute of Hydrology who have been involved in SEBEX: Alistair Culf, John Gash, Richard Harding, Cathy Holwill, Jim Wallace and Ivan Wright. They are also grateful to M. Sivakumar and S. Abdoulsalam from the ICRISAT Sahelian Center in Sadoré, Niger.

\section{REFERENCES}

Allen, S.J., Wallace, J.S., Gash, J.H.C. and Sivakumar, M.V.K. 1994. 'Measurements of albedo variation over natural vegetation in the Sahel', Int. J. Climatol., 14, 625-636.

Blyth, E.M. and Harding, R.J. 1995. 'Application of aggregation models to surface heat flux from the Sahelian tiger bush', Agric. Forest. Meteorol., 72, 213-235.

Bolle, H.J., Andre, J.C., Arrue, J.L., Barth, H.K., Bessemoulin, P., Brasa, A., de Bruin, H.A.R., Cruces, J., Dugdale, G., Engman, E.T., Evans, D.L., Fantechi, R., Fiedler, F., van de Griend, A., Imeson, A.C., Jochum, A., Kabat, P., Kratzsch, T., Lagouarde, J.-P., Langer, I., Llamas, R., Lopez-Baeza, E., Melia Miralles, J., Muniosguren, L.S., Nerry, F., Noilhan, J., Oliver, H.R., Roth, R., Saatchi, S.S., Sanchez Diaz, J., de Santa Olalla, M., Shuttleworth, W.J., Sogaard, H., Stricker, H., Thornes, J., Vauclin, M. and Wickland, D. 1993. 'EFEDA: European field experiment in a desertification threatened area', Ann. Geophys., 11, $173-189$.

Culf, A.D. and Gash, J.H.C. 1993. 'Longwave radiation from clear skies in Niger: a comparison of observations with simple formulae', J. Appl. Meteorol., 32, 539-547.

Culf, A.D., Allen, S.J., Gash, J.H.C., Lloyd, C.R. and Wallace, J.S. 1993. 'Energy and water budgets of an area of patterned woodland in the Sahel', Agric. Forest Meteorol., 66, 65-80.

Druilhet, A. and Tinga, A. 1982. 'Présentation de l'Expérience ECLATS', La Météorologie, 29-30, $227-237$.

Garratt, J.R. 1978. 'Flux-profile relation above tall vegetation', Q.J.R. Meteorol. Soc., 104, 199-212.

Garratt, J.R. 1992. The Atmospheric Boundary Layer, Cambridge Atmospheric and Space Science Series, Cambridge University Press, 316 pp.

Gash, J.H.C., Wallace, J.S., Lloyd, C.R., Dolman, A.J., Sivakumar, M.V.K. and Renard, C. 1991. 'Measurements of evaporation from fallow Sahelian savannah at the start of the dry season', Q.J.R. Meteorol. Soc., 117, 749-760.

Goutorbe, J-P., Lebel., T., Tinga, A., Bessemoulin, P., Brouwer, J., Dolman, A.J., Engman, E.T., Gash, J.H.C., Hoepffner, M., Kabat, P., Kerr, Y.H., Monteny, B., Prince, S., Said, F., Sellers, P. and Wallace, J.S. 1994. 'HAPEX-Sahel: a large scale study of land atmosphere interactions in the semi-arid tropics', Ann. Geophys., 12, 53-64.

ICIIHI 1986. The Encroaching Desert: the Consequences of Human Failure: a Report for the Independent Commission on International Humanitarian Issues, Zed Books Ltd, London, 132 pp.

Jackson, R.D., Reginato, R.J. and Idso, S.B. 1977. 'Wheat canopy temperature: A practical tool for evaluating water requirements', Water Res. Res., 13, 651-656.

Kerr, Y.H., Assad, E., Freleaud, J.P, Lagouarde, J.P. and Seguin, B. 1987. 'Estimation of evapotranspiration in the Sahelian zone by use of METEOSAT and NOAA AVHRR data', Adv. Space Res., 7, 161-164.

Lagouarde, J-P. and McAneney, K.J. 1992. 'Daily sensible heat flux estimation from a single measurement of surface temperature and maximum air temperature', Boundary Layer Meteorol., 59, 341-362.

Mayocchi, C.L. and Bristow, K.L. 1995. 'Soil surface heat flux: some general questions and comments on measurements', Agric. Forest Meteorol., 75, 43-50.

Moncrieff, J.B., Monteny, B., Verhoef, A., Friborg, Th., Elbers, J.H., Kabat, P., de Bruin, H.A.R., Soegaard, H., Jarvis, P.G. and Taupin, J.D. 1997. 'Spatial and temporal variations in net carbon flux during HAPEX-Sahel', J. Hydrol., 188-189, 563-588.

Oke, T.R. 1987. Boundary-Layer Climatology, Methuen, New York, 435 pp.

Oliver, H.R. and Wright, I.R. 1990. 'Correction of errors associated with measurement of net all-wave radiation with double-domed radiometers (Research Note)', Boundary-Layer Meteorol., 53, 401-407.

Pagès, J-P., Frangi, J-P, Durand, P., Estournel, C. and Druilhet, A. 1988. 'Étude de la couche limite de surface Sahelienne-Experience Yantala', Boundary-Layer Meteorol., 43, 183-203.

Sandholt, I. and Steen Andersen, H. 1993. 'Derivation of actual evapotranspiration in the Senegalese Sahel, using NOAA-AVHRR data during the 1987 growing season', Remote Sens. Environ., 46, 164-172.

Seguin, B., Assad, E., Freteaud, J.P., Imbernon, J., Kerr, Y. and Lagouarde, J.P. 1989. 'Use of meteorological satellites for water balance monitoring in Sahelian regions', Int. J. Remote Sensing, 10, 1101-1117. 
Sellers, P.J., Hall, F.G., Asrar, G., Strebel, D.E and Murphy, R.E. 1988. 'The first ISLSCP field experiment (FIFE)', Bull. Am. Meteorol. Soc., 69, 22-27.

Shuttleworth, J.W., Gash, J.H.C., Lloyd, C.R., McNeill, D.D., Moore, C.J. and Wallace, J.S. 1988. 'An integrated micrometerological system for evaporation measurement', Agric. Forest Meteorol., 43, 295-317.

Søgaard, H. 1988. 'Estimation of the surface energy balance in the Sahelian zone of Western Africa', Geogr. Tidsskrift, 88, $108-115$.

Stewart, J.S. and Thom, A.S. 1973. 'Energy budgets in pine forest', Q.J.R. Meteorol. Soc., 99, 154-170.

Verhoef, A. 1995. Surface energy balance of shrub vegetation in the Sahel. PhD Thesis, Dept. of Meteorology, WAU, Wageningen, the Netherlands, ISBN 90-5485-458-8, $247 \mathrm{pp}$.

Von Maydell, H.-J. 1990. Trees and Shrubs of the Sahel: their Characteristics and Uses, Margraf, Weikersheim, Germany.

Wallace, J.S., Allen, S.J., Culf, A.D., Dolman, A.J., Gash, J.H.C., Holwill, C.J., Lloyd, C.R., Stewart, J.B. and Wright, I.R. 1992. SEBEX: The Sahelian energy balance experiment, Final report on ODA Project T06050C1, ODA-report 92/9.

Wallace, J.S. and Holwill 1997. 'Soil evaporation from tiger-bush in Niger', J. Hydrol., 188-189, 426-442..

Wessels, W. 1993. 'De Nederlandse ontwikkelingssamenwerking met de Sahel', Informatie Voorlichtingsdienst Ontwikkelingssamenwerking van het ministerie van Buitenlandse Zaken 15, 1-8. 